\title{
ペルオキシソームの形成・機能と遺伝病：ABCトランスポーターを中心に
}

\author{
今中常雄 ${ }^{\dagger}$
}

\section{Biogenesis, the Function of Peroxisomes, and Their Role in Genetic Disease: With a Focus on the ABC Transporter}

\author{
Tsuneo Imanaka ${ }^{\dagger}$ \\ Department of Biological Chemistry, Graduate School of Medicine and Pharmaceutical \\ Sciences, University of Toyama; 2630 Sugitani, Toyama 930-0194, Japan.
}

(Received March 6, 2018)

\begin{abstract}
Peroxisomes are organelles that are present in almost all eukaryotic cells. These organelles were first described in 1954, in the cytoplasm of the proximal tubule cells in the mouse kidney, using electron microscopy by Rhodin and referred to as "microbodies". Then, de Duve and Baudhuin isolated microbodies from rat liver using density gradient centrifugation, defined the microbodies as membrane-bound organelles containing several $\mathrm{H}_{2} \mathrm{O}_{2}$-producing oxidases and $\mathrm{H}_{2} \mathrm{O}_{2}$-degrading catalase, and named them peroxisomes. At present, the biogenesis of peroxisomes in mammals involves three different processes: the formation of pre-peroxisomes from the endoplasmic reticulum, the import of peroxisomal membrane and matrix proteins to the pre-peroxisomes, and the growth and division of the peroxisomes. These organelles are involved in a variety of metabolic processes, including the $\beta$-oxidation of very long chain fatty acids, and the synthesis of ether phospholipids and bile acids in mammals. These metabolic pathways require the transport of metabolites in and out of peroxisomes. The transport of such metabolites is facilitated in part by the ATP-binding cassette (ABC) transporter. Impairment of the biogenesis and function of peroxisomes causes severe peroxisomal disorders. Since I began peroxisome research at Professor de Duve's laboratory in 1985, I have studied the biogenesis and function of peroxisomes and peroxisome diseases for more than 30 years, with a focus on $\mathrm{ABC}$ transporters. Here, I review the biogenesis of peroxisomes, the targeting of $\mathrm{ABC}$ transporters to the peroxisome, and the function of $\mathrm{ABC}$ transporters in physiological and pathological processes, including X-linked adrenoleukodystrophy, a neurodegenerative disease.
\end{abstract}

Key words_ - peroxisome; biogenesis; ATP-binding cassette transporter; fatty acid $\beta$-oxidation; peroxisome disease; $\mathrm{X}$-linked adrenoleukodystrophy

\section{1. はじめに}

ペルオキシソームは真核細胞に広く分布し，ヒト では極長鎖脂肪酸の $\beta$ 酸化，エーテル型リン脂質 の生合成, コレステロールの胆汁酸への変換など, 脂質代謝に重要な役割を担っている. 一方，ペルオ キシソームの形成異常やペルオキシソームタンパク 質の欠損は，いわゆるペルオキシソーム病と呼ばれ る重篤な疾患と原因なる。私は，1985 年 Rockefeller 大学 (New York) の Prof. de Duve 研究室 でペルオキシソームの形成機構に関する研究に携わ

富山大学大学院医学薬学研究部分子細胞機能学研究室 (厂930-0194 富山市杉谷 2630)

現所属: †広島国際大学薬学部（T737-0112 広島県吳 市広古新開 5-1-1)

e-mail: imanaka@ps.hirokoku-u.ac.jp

本総説は, 平成 28 年度退職にあたり在職中の業績を中 心に記述されたものである.
る機会を得た（Fig. 1)．それ以来，30 年以上にわ たり「ペルオキシソームATP-binding cassette (ABC) タンパク質を中心にペルオキシソームの形 成・機能並びに遺伝病」に関する研究に取り組んで きた. ペルオキシソームは 1954 年に初めて発見さ れたオルガネラである.よって，60 年余りに及ぶ ペルオキシソームに関する研究の歴史の中で, ちょ うど後半部分に携わってきたことになる. 研究の進 展には感慨深いものがある.これまでの私たちの研 究成果を中心にペルオキシソームを眺めてみたい.

2. ペルオキシソームとは

ペルオキシソームは一重膜で囲まれたオルガネラ であり，哺乳動物細胞に広く分布している（Fig. 2). 細胞によりペルオキシソームの形や大きさは異 なるが，おおよその直径は 0.1-1 $\mu \mathrm{m}$ である。ペル オキシソームは, 1954 年にスウェーデンの大学院 




Fig. 1. Prof. de Duve in His Laboratory of Biochemical Cytology at Rockefeller University in 1987

Prof. de Duve stands close to the centrifuge that he developed.



Fig. 2. Electron Micrograph of Rat Liver Peroxisomes

P, Peroxisome. The bar, $1 \mu \mathrm{m}$. Courtesy of Sadaki Yokota (Professor emeritus at Yamanashi University).

生 Rhodin がマウス腎臟の近位尿細管細胞を電子顕 微鏡で観察した際に発見された。彼の学位論文でミ クロボディー（microbody）と記載されている.1) その後, 1965 年に de Duve と Baudhuin は, ラッ 卜肝臓から粗オルガネラ分画を調製し, 密度勾配遠 心によりミクロボディーを他のオルガネラから分離 することに成功した．ミクロボディーには $\mathrm{H}_{2} \mathrm{O}_{2}$ を 産生する数種のオキシダーゼと $\mathrm{H}_{2} \mathrm{O}_{2}$ を分解する力 タラーゼが局在していることより，彼らはミクロボ ディーをペルオキシソームと呼ぶことを提唱し た. ${ }^{2)}$

1976 年，Lazarow と de Duve はマウス肝臓のぺ
ルオキシソームにシアン非感受性の脂肪酸 $\beta$ 酸化 系が存在することを発見し，この活性が高脂血症薬 クロフィブラートで顕著に誘導されることを示し

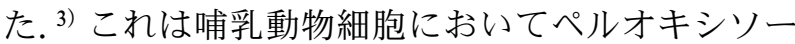
ムの生理的機能が記載された初めての報告である.

一方, 1964 年 Bowen らは, cerebro-hepato-renal syndrome（Zellweger 病）が遺伝的疾患であること を示した. ${ }^{4)} そ の$ 後, Goldfischer らは Zellweger 病 患者ではペルオキシソームが欠損していることを発 見した。 ${ }^{5)}$ 間もなく，ペルオキシソームはヒトの生 命活動に必須であることが認識されるようになつた.

今日では，ヒトを含めた哺乳動物において，ペル オキシソームは脂質代謝に必須のオルガネラであ り, 生体の恒常性維持に重要な役割を担っているこ とが明らかになっている，中枢神経系の細胞では, ペルオキシソームのサイズは肝臓や腎臟に比べて小 さいが，神経系の発達に重要である. ${ }^{6)}$ また，ペル オキシソームがヒトの発育や健康に欠くべからざる オルガネラであることは，ペルオキシソームが係わ る多くの先天代謝異常症からも窺える.

現在までに，ヒトでは 120 以上のペルオキシソー 厶関連遺伝子が同定され，20 以上の遺伝病がペル オキシソーム病に分類されている. ${ }^{7)}$ さらにペルオ キシソームはダイナミックに変化するオルガネラで あり，栄養状態や環境の変化により，その数とサイ ズが顕著に増減する。ヒトでは絶食, 糖尿病, 高脂 肪食などがペルオキシソームの数の増加を誘導する ことが知られている. ${ }^{8}$

1985 年, 私がペルオキシソームの研究に参加し た当時は，ラット肝臓での脂肪酸 $\beta$ 酸化系酵素の 精製や遺伝子クローニングが始まった頃であった。

また，ペルオキシソームタンパク質が遊離型ポリ ソームで翻訳されることがわかり，ペルオキシソー ム形成に係わる研究が新たな局面を迎えていた。ペ ルオキシソーム病については, 患者線維芽細胞での



今中常雄
1975 年広島大学医学部薬学科卒, 77 年 同大学院薬学研究科修士課程修了. 85 年薬学博士. 77 年帝京大学薬学部助手. 85 年米国ロックフェラー大学研究員. 88 年帝京大学薬学部講師, 97 年同助教 授. 98 年富山医科薬科大学薬学部教授, 2005 年富山大学薬学部教授. 17 年広島 国際大学薬学部客員教授。専門は生化 学・分子細胞生物学. 
研究が始まつた，振り返ってみるとペルオキシソー 么研究の黎明期の感がある.

なお，ペルオキシソームと共通の形成機構を持つ オルガネラとして，解糖系の諸酵素が局在している 原虫グリコソーム (glycosome), ${ }^{9)}$ 多細胞生物であ る糸状菌の細胞が障害された際，細胞間をつなぐ隔 壁孔を塞ぎ細胞質の流出を防ぐウオロニンボディ (Woronin body), ${ }^{10)}$ 植物の発芽に係わるグリオキ シソーム (glyoxysome) がある. ${ }^{11)}$ オルガネラの多 様性・機能の観点から興味深い.

\section{3. ペルオキシソームの形成機構}

3-1. ペルオキシソーム形成の概要 1960-70 年代, ペルオキシソームと小胞体が密に近接してい るという電子顕微鏡観察から，ペルオキシソームは 小胞体から出芽して形成されると考えられてい た. ${ }^{12)} 1980$ 年代, ペルオキシソームタンパク質が遊 離型ポリソームで生合成されることが明らかにな り，ペルオキシソームはミトコンドリアと同じよう に，既に存在しているペルオキシソームに新たに生 合成されたペルオキシソームタンパク質が輸送さ れ，分裂を経て形成されるという考えが主流になつ た. ${ }^{13)}$ 私も当時そう考えていた. その後，ペルオキ シオームの形成に係わる因子（タンパク質を peroxin, 遺伝子を $P E X$ と呼ぶ)が同定されてきた.

$P E X 3$ や PEX19 遺伝子に異常がある細胞ではペル オキシソームが検出されず, 野生型遺伝子を導入す るとペルオキシソームが形成されること，新たに生 合成された Pex3p（遺伝子 PEX3 から翻訳された タンパク質を Pex3p と略称する) は，小胞体へ輸 送されるなどの知見が得られてきた。 これらの知見 を基に現在では，ペルオキソームはその前駆体が小 胞体から出芽し, 遊離型ポリソームで生合成された ペルオキシソームタンパク質が前駆体に輸送され, 成熟したペルオキシソームが形成されると考えられ ている（Fig. 3). ${ }^{14)}$ しかしながら，小胞体のどこか ら出芽するかなど解析すべき課題は残っている.

このように時代の最新技術を用いた研究によりぺ ルオキシソーム形成のモデルが提唱され，技術の進 展に伴う新たな知見から，モデルが変遷しているこ とは興味深い。半世紀を経てペルオキシオームの出 発点が小胞体に戻った感がある。現在までに 36 種 類の $P E X$ 遺伝子が同定され，個々の $P E X$ 遺伝子 の異常が重篤なペルオキシソーム形成異常症の原因



Fig. 3. Biogenesis of Peroxisome

A pre-peroxisome containing Pex $3 p$ and Pex $16 p$ is budded from ER Newly synthesized peroxisomal membrane and matrix proteins are post-translationally imported to pre-peroxisome. After fusion of pre-peroxisomes, mature peroxisome is formed. The number of peroxisome increases by division. PMP, peroxisomal membrane protein.

となる.

3-2. ペルオキシソームマトリックスタンパク質 の輸送機構 ミトコンドリアと異なりペルオキシ ソームは DNA を持っていないので，すべてのペル オキシソームタンパク質は核の DNA にコードされ ている. $\left[{ }^{35} \mathrm{~S}\right]$ メチオニンを用いたタンパク質生合 成のパルスーチェイス実験などにより，ペルオキシ ソームマトリックスタンパク質は翻訳後にペルオキ シソームに輸送されることが予想された.

Rockefeller 大学での私の最初のテーマは, ペル オキシソームタンパク質の in vitro 輸送系を構築 し, 輸送メカニズムの詳細を解析することであっ た. ペルオキシソームの主要タンパク質の 1 つであ る acyl-CoA oxidase に着目した. Acyl-CoA oxidase の mRNA を $\left[{ }^{35} \mathrm{~S}\right]$ メチニンを添加した reticulocyte lysate で翻訳し，ラット肝臓より精製したペル オキシソームと incubation し, proteinase 処理によ りペルオキシソーム内に取り込まれた acyl-CoA oxidase の量をフルオログラフィーで定量化した. ペルオキシソームを壊れないように取り扱うこと, acyl-CoA oxidase は成熟型タンパク質として生合成 されるので，ペルオキシソーム膜に結合した acylCoA oxidase とペルオキシソーム内に輸送されたも のを区別する条件の設定に苦労した。輸送にATP の加水分解が必要であること, ペルオキシソーム膜 に受容体があること, 細胞質因子で輸送が促進され ることなどを明らかにした（Fig. 4). 細胞質因子 は今でいうPex5p であったのだろうか。この成果 


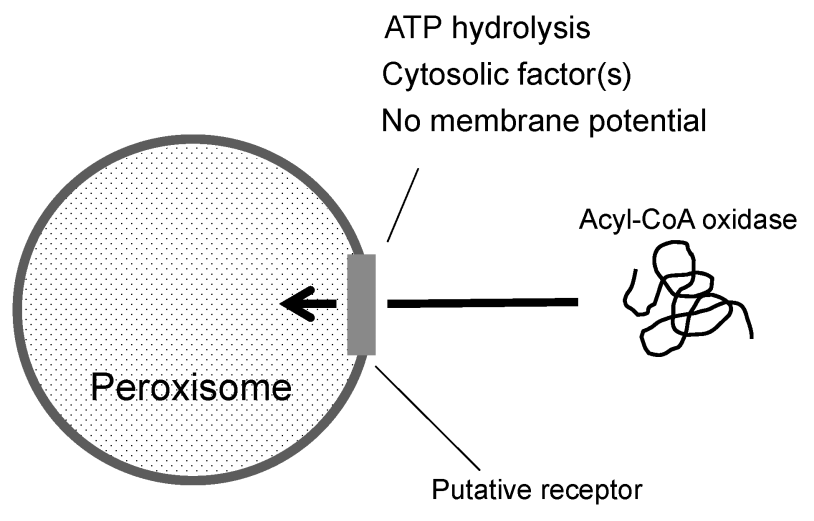

Fig. 4. Translocation of Acyl-CoA Oxidase into Peroxisome $\left.{ }^{[35} \mathrm{S}\right]$ acyl-CoA oxidase (AOx) is incorporated into peroxisomes in a proteinase K-resistant fashion. The import of AOx into peroxisomes could be dissociated into two steps: Binding occurs at $0^{\circ} \mathrm{C}$ in the absence of ATP; Translocation occurs only at $26^{\circ} \mathrm{C}$ and requires the hydrolysis of ATP. Translocation is not inhibited by ionophores.

は 1987 年の J. Cell Biol. に報告した. ${ }^{15)}$ ちょうど 私の論文の後にカリフォルニア大学の大学院生で あった Gould が，ホタルの luciferase（ホタルの発 光器官細胞のペルオキシソームに存在する）を CV-1 monkey 細胞に発現させ, $\mathrm{COOH}$ 末端 12 ア ミノ酸にペルオキシソーム移行シグナルがあること を報告した. ${ }^{16)}$ ペルオキシソーム形成に関する新し い知見が並んで発表されたことに驚いた。1988 年，彼らは $\mathrm{COOH}$ 末端の Ser-Lys-Leu（SKL）が ペルオキシソーム移行シグナルであることを示し た. ${ }^{17)}$

その後, ペルオキシソーム移行シグナルの受容体 は細胞質のPex5p と Pex7p であること，この受容 体とペルオキシソームタンパク質複合体はペルオキ シソーム膜の pore を通ってペルオキシソーム内に 取り込まれること，受容体は再度細胞質に戻って利 用されることなどが明らかにされた（Fig. 5).

すなわち, ペルオキシソームマトリックスタンパ ク質は, $\mathrm{COOH}$ 末端にトリペプチド $(\mathrm{S} / \mathrm{A} / \mathrm{C})-(\mathrm{K} /$ $\mathrm{R} / \mathrm{H})$ - (L/M) からなるペルオキシソーム移行シグ ナル (PTS1) 若しくは $\mathrm{NH}_{2}$ 末端に $(\mathrm{R} / \mathrm{K})-(\mathrm{L} / \mathrm{I} / \mathrm{K})$ $\mathrm{X} 5-(\mathrm{Q} / \mathrm{H})-(\mathrm{L} / \mathrm{I} / \mathrm{V})$ からなる PTS2 を持っている. 新たに生合成された PTS1 を持つタンパク質は細胞 質で Pex5p に認識される。哺乳動物ではスプライ シングの違いによる 2 種類の Pex $5 \mathrm{pL}$ と Pex5pS が 存在する。一方, $\mathrm{NH}_{2}$ 末端の PTS2 は Pex7p に認 識される，Pex7p はペルオキシソームへの移行に Pex5pL との結合を必要とする. ペルオキシソーム

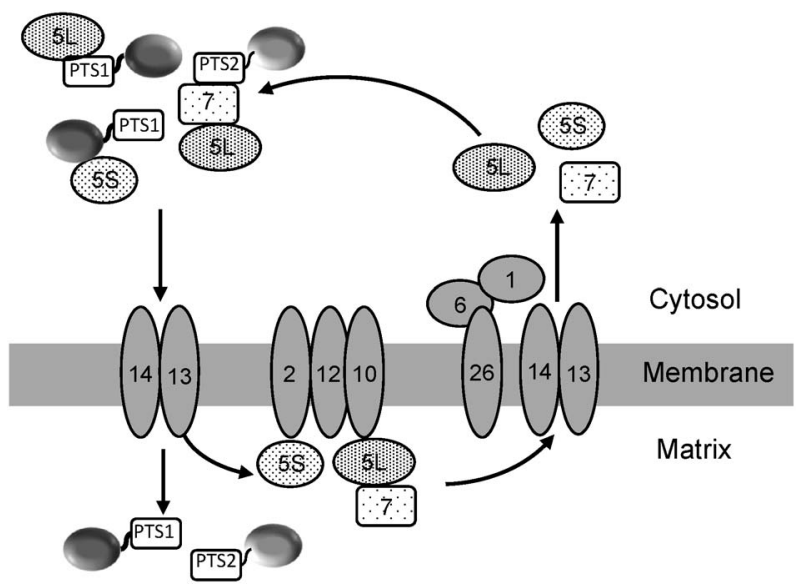

Fig. 5. Import of Newly Synthesized Peroxisomal Matrix Proteins into Peroxisome

A set of peroxins are involved in the process (See the text). The number in each oval indicates the sequential number of peroxin.

マトリックスタンパク質を結合した Pex $5 \mathrm{p}$ と Pex7p は Pex14p とPex13p からなるペルオキシソーム膜 上のドッキングタンパク質と結合し，複合体はペル オキシソーム内に輸送される。 その後, マトリック スタンパク質と解離した Pex 5p やPex7p はペルオ キシソーム膜から細胞質に輸送され，輸送サイクル を繰り返すかプロテアソームで分解される. ${ }^{18,19)} こ$ の過程では Pex2p，Pex10p やユビキチンリガーゼ 活性を持つPex12p が係わる。Pex12p はレセプ ターをモノユビキチン化若しくはポリユビキチン化 する. ユビキチン化された Pex5pL, Pex5pS, Pex7p はPex14p と Pex13p からなるドッキングタンパク 質と結合し，細胞質に逆輸送される。その際，細胞 質に存在する ATPases associated with diverse cellular activities (AAA) ファミリーに属する Pex1p と ペルオキシソーム膜上の Pex26p と結合している Pex6p の 6 量体がペルオキシソーム膜からのユビキ チン化された Pex5p の遊離に係わっている. ${ }^{20)}$ な お，モノユビキチン化された受容体はマトリックス タンパク質輸送に再利用され，ポリユビキチン化さ れた受容体は分解される.

生合成されたペルオキシソームタンパク質が細胞 質で受容体と結合することは予想外であった。ま た，この複合体がそのままペルオキシソーム膜の pore を通過する．その際 pore は一旦開いてまた閉 じる. 受容体のリサイクリングはユビキチン化で制 御される.このようにペルオキシソームタンパク質 の膜透過はユニークである，真核生物は，細胞質で 
翻訳された微量のペルオキシソームタンパク質を正 しくかつ効率よくペルオキシソームに輸送するため に，このような複雑な仕組みを獲得したと思われる.

\section{3-3. ペルオキシソーム膜形成の分子機構}

1980 年代, Zellweger 病ではペルオキシソームが 検出されないことより，ペルオキシソーム膜タンパ ク質の生合成に異常があり，ペルオキシソーム自体 が欠損しているのではないかと考えられていた．私 たちはラット肝臓より精製したペルオキシソーム膜 タンパク質に対する抗体を作製し，Zellweger 病患 者線維芽細胞を用いてペルオキシソーム膜タンパク 質の挙動を解析した。すると興味深いことに，ペル オキシソーム膜タンパク質はショ糖密度勾配遠心で 比重 1.18 の位置に沈降し, 他のオルガネラにミス ターゲティングしていないことが示唆された.さら に蛍光抗体法や免疫組織学による細胞の観察によ り，マトリックスタンパク質を含まないペルオキシ ソーム膜顆粒が存在していることを明らかにし， ペ ルオキシソーム膜ゴーストと名付けた. ${ }^{21,22)}$ この結 果は, ペルオキシソーム形成において膜タンパク質 の輸送はマトリックスタンパク質の輸送とは異なる こと, Zellweger 病ではペルオキシソーム膜は形成 されるがマトリックスタンパク質の輸送に障害を持 つ例があることを示している.

その後, $70 \mathrm{kDa}$ ペルオキシソーム膜タンパク質 （PMP70）を用いる in vitro 輸送系を構築し, PMP70 の輸送には, PTS1 やPTS2 とは異なる輸 送シグナルが $\mathrm{NH}_{2}$ 末端側に存在すること, 膜上に 受容体が存在すること, 細胞質因子が存在すること, ATP の加水分解は必要ないことなどを示した. ${ }^{23)}$ しばらくして, Pex19p と Pex3p がペルオキシソー ムの膜形成に必要であることが明らかにされた.

Pex19p は生合成された各種のペルオキシソーム膜 タンパク質と選択的に結合し疎水性のペルオキシ ソーム膜タンパク質を可溶性に保つ分子シャペロン 様の役割を担い，ペルオキシソーム膜上の Pex3p と相互作用し，膜タンパク質をペルオキシソームに 挿入していることが示唆された. ${ }^{24)}$ 私たちは京都大 学の加藤教授との共同研究でペルオキシソーム膜夕 ンパク質局在化の分子機構を構造生物学の立場から 明らかにすることを試みた。精製 Pex19p は可溶性 であったが，数十 $\mathrm{mg} / \mathrm{mL}$ の濃度でも結晶化しな かった。一方, Pex19p は $\mathrm{NH}_{2}$ 末端 44 アミノ酸に

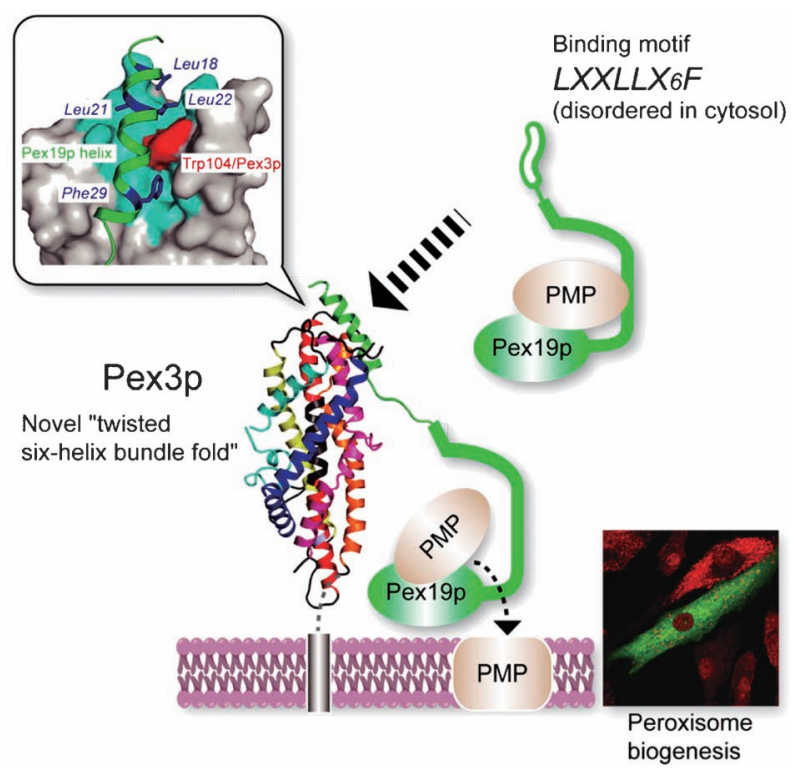

Fig. 6. Targeting of Peroxisomal Membrane Protein to Peroxisomal Membrane

After being translated in free polysomes, peroxisomal membrane protein is recognized and become bound to Pex19p through the Pex19p binding motif located in the $\mathrm{NH}_{2}$-terminal region. The interaction is strengthened by sequences located downstream in the TMDs. Pex19p maintains the peroxisomal membrane proteins in a soluble and proper conformation in the cytosol. Then, the peroxisomal membrane protein-Pex19p complex docks at the peroxisomal membrane via association with its docking factor, Pex3p. Finally, the peroxisomal membrane protein is inserted into the peroxisomal membrane and Pex19p shuttles back to the cytosol to initiate another import cycle (See text). (Color figure can be accessed in the online version.)

Pex3p との結合領域があり, 91 番目のアミノ酸以 降にペルオキシソーム膜タンパク質との結合領域が あった. ${ }^{25)}$ そこで, Pex3pの $\mathrm{NH}_{2}$ 末端膜貫通領域 を除いた細胞質領域（aa.49-373）とPex19p の $\mathrm{NH}_{2}$ 末端領域（a.1-44）を複合体として結晶化さ せることに成功した。 Pex3p は， 2 番目の $\alpha$ ヘリッ クスを軸に 6 つ逆平行性の $\alpha$ ヘリックスが束に なつたユニークな棈円構造をとり，その先端部分で Pex19pの 16 アミノ酸残基からなる $\alpha$ ヘリックス構 造と結合していた。その結合は, Pex3pの Trp ${ }^{104}$ と Pex19p の $\mathrm{Leu}^{18,21,22}, \mathrm{Phe}^{29}$ の間での疎水性結合 を介していた（Fig. 6). ${ }^{26)}$

野生型 Pex3p は Pex19p に高い親和性を示し，そ の解離定数は約 $3 \mathrm{nM}$ であり, Trp ${ }^{104}$ を Ala に置換

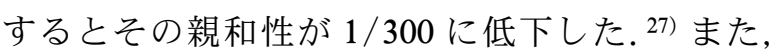

Pex19p を欠損した Zellweger 病患者線維芽細胞に 野生型 cDNA を導入すると約 5 日後にペルオキシ ソームが形成されたことが確認できた.一方, Pex3p との結合に関与しないLeu26Ala の変異型 cDNA の導入では約 5 日後にペルオキシソームが形成され 
たが，Leu22Ala や Phe29Ala の変異ではペルオキ シソームは形成されなかった。よって，生体内でも この相互作用を介してペルオキシソーム膜が形成さ れていることが推測される。一方，試験管内での Pex3p とPex19p との解離定数は, Pex19p がペル オキシソーム膜タンパク質と複合体を形成していて もいなくても変わらない. よってペルオキシソーム 膜上には，Pex19pがペルオキシソーム膜タンパク 質をペルオキシソーム膜に降ろした後, Pex3p との 解離を促進するタンパク質が存在すると予想される.

\section{3-4. ABCD タンパク質の局在化機構 $\mathrm{ABC}$} タンパク質サブファミリー D には ABCD1-4の 4 種のタンパク質が同定されている。 これらは， $\mathrm{NH}_{2}$ 末端側の 6 つの膜貫通へリックスからなる膜貫通ド メイン（transmembrane domain; TMD）とそれに 続くヌクレオチド結合ドメイン (nucleotide-binding domain; NBD）から構成されている（Fig. 7).

ABCD1-4 は, 当初 adrenoleukodytrophy protein (ALDP), ALDP related protein (ALDRP), PMP70, PMP70 related protein (P70R) と呼ばれた.

ABCD1-3 はペルオキシソーム膜に, ABCD4 はリ ソソーム膜に局在している。これらタンパク質の局 在化に関しては， $\mathrm{NH}_{2}$ 末端側から数えて 1 番目の TMD（TMD1）の $\mathrm{NH}_{2}$ 末端に位置する疎水性セグ メント（H0 モチーフ）が重要な役割を果たしてい る. ${ }^{28)} \mathrm{ABCD} 1-3$ は遊離型ポリソームでの翻訳中に Pex19p に捕捉され，ペルオキシソームへと輸送さ れる。一方，ABCD4 は H0 モチーフを欠くために Pex19p とは結合できず TMD1 を含む領域がシグナ ル認識粒子（signal recognition particle; SRP）に捕 捉され，小胞体に局在化しリソソームへと移行する (Fig. 8). GTOP データベースによれば，哺乳動物 $\mathrm{ABCD}$ タンパク質ホモログを持つ 193 生物種のう ち，疎水性プロットが可能であつた 143 種について みると，60 種の生物で H0 モチーフを持たない $\mathrm{ABCD}$ タンパク質が存在することが確認できた. $\mathrm{ABCD}$ タンパク質局在化におけるオルガネラ選択 性は種を越えて保存されていると思われる. ${ }^{29)}$

私たちは，ペルオキシソーム膜タンパク質 ABCD3について詳細な解析を行つてきた. $\mathrm{ABCD} 3$ の局在化シグナルについて, $\mathrm{ABCD} 3$ の $\mathrm{NH}_{2}$ 末端側や $\mathrm{COOH}$ 末端側を欠失させ green fluorescent protein（GFP）を融合させた construct



Fig. 7. Hypothesized Structure of the Peroxisomal ABC Transporter

The transporter is a half-size $\mathrm{ABC}$ transporter with one transmembrane domain (TMD) and one nucleotide-binding domain (NBD). Six transmembrane helices are located in the $\mathrm{NH}_{2}$-terminal half of the transporter, and Walker A, B and ATP-binding Cassette signature sequence (the ABC signature) is located in the $\mathrm{COOH}$-terminal half of the transporter. In mammals, three $\mathrm{ABC}$ proteins belonging to subfamily $\mathrm{D}, \mathrm{ABCD} 1, \mathrm{ABCD} 2$ and $\mathrm{ABCD} 3$ exist in peroxisomes, predominately as a homodimer. Walker A motif is a motif in proteins that is associated with phosphate binding. The motif has consensus sequence GXXXXGKT/S. It is present in many ATP or GTP utilizing proteins. Walker B motif is situated downstream of the A-motif. The consensus sequence is hhhhDE (h: hydrophobic amino acid). The motif is involved in ATP hydrolysis through binding of $\mathrm{Mg}^{2+}$ to the aspartate residue. The $\mathrm{ABC}$ signature is a conserved sequence (LSGGQ) identified in the NBD of all ABC transporters.

ABCD1, ABCD2, ABCD3

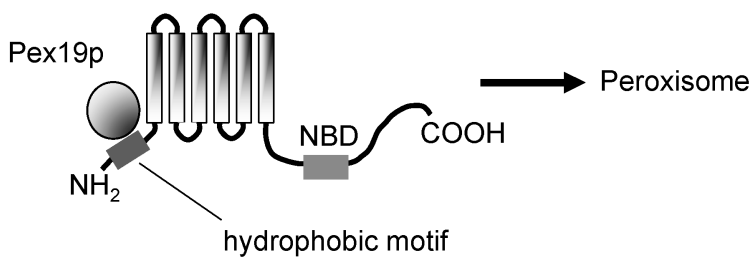

$\mathrm{ABCD} 4$

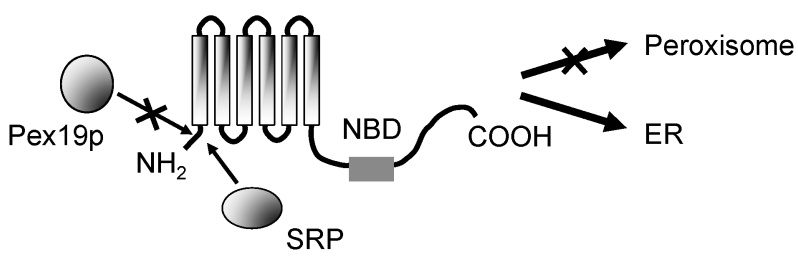

Fig. 8. Targeting and Localization of ABCD Proteins

For the trafficking of $\mathrm{ABCD}$ proteins, an $\mathrm{NH}_{2}$-terminal $\mathrm{H} 0$ motif plays an important role. $\mathrm{ABCD} 1-3$ possessing $\mathrm{H} 0$ motif are selectively captured by Pex19p and destined for peroxisomes. In contrast, ABCD4 hardly interacts with Pex19p because of its lack of the H0 motif, and as a result, ABCD4 is recognized by signal recognition particle (SRP) and integrated into the ER membrane. Subsequently, ABCD4 is transported to lysosomes. 
を $\mathrm{CHO}$ 細胞に発現させることによりペルオキシ ソーム局在化を解析した. ${ }^{30,31)}$ TMD1 と TMD2 を 含む ABCD3 (AA.1-144)-GFP 並びに TMD5 と TMD6 を含む GFP-ABCD3（AA.263-375）はペル オキシソームへ局在した。 さらに $\mathrm{NH}_{2}$ 末端側や $\mathrm{COOH}$ 末端側を欠失させた $\mathrm{ABCD} 3$ と Pex19 との 結合性を解析すると, ABCD3 は $\mathrm{NH}_{2}$ 末端の $\mathrm{Leu}^{21}$ $\mathrm{Leu}^{22}$ Leu $^{23}$ と TMD5-TMD6 の領域で Pex19p と選 択的に結合した。ささにターゲティングに必要な領 域として, 疎水性アミノ酸配列 $\mathrm{Leu}^{21}-\mathrm{Leu}^{22}-\mathrm{Leu}^{23}$ に続く $\mathrm{Ile}^{70}-\mathrm{Leu}^{71}$ と TMD5 と TMD6 に隣接した $\mathrm{Ile}^{307}-\mathrm{Leu}^{308}$ が同定された。よって ABCD3 は翻訳 中に $\mathrm{NH}_{2}$ 末端の $\mathrm{Leu}^{21}-\mathrm{Leu}^{22}-\mathrm{Leu}^{23}$ を含む領域（H0 モチーフ）でPex19p と結合し，さらにPex19p と TMD5-TMD6 の結合で複合体が安定化し, Ile ${ }^{70}$ $\mathrm{Leu}^{71}$ と $\mathrm{Ile}^{307}-\mathrm{Leu}^{308}$ を含む領域でペルオキシソー 厶膜に存在する受容体と結合する可能性が示唆され た (Fig. 9)。ABCD1 や ABCD2 についても同様の アミノ酸配列が Pex19p との結合とペルオキシソー ムへの局在化に係わっていると予想される. ${ }^{32)}$

一方， $\mathrm{ABCD} 4$ は， $\mathrm{ABCD} 1$ 及び $\mathrm{ABCD} 2$ とのホ モロジー検索によって見い出され，当初はペルオキ シソームに局在するとされていた。 しかしながら私 たちは，CHO 細胞に安定過剩発現させた ABCD4 がペルオキシソームではなく小胞体に局在するこ と，それは ABCD4 がペルオキシソームへの局在化 に必須な H0 モチーフを欠くためであることを明ら かにしてきた. ${ }^{28)}$

最近, $\mathrm{ABCD} 4$ を欠損するビタミン $\mathrm{B}_{12}$ 欠乏症患 者が発見され, 患者線維芽細胞ではリソソームにビ タミン $\mathrm{B}_{12}$ が蓄積していることより，ABCD4 はリ ソソーム内から細胞質にビタミン $\mathrm{B}_{12}$ を排出するト ランスポーターである可能性が指摘された. ${ }^{33)}$ ま た，アダプタータンパク質としての機能を持つと予 想されるリソソーム膜タンパク質 LMBD1 を欠損 してもリソソームにビタミン $\mathrm{B}_{12}$ が蓄積するビタミ ン $\mathrm{B}_{12}$ 欠乏症の原因になることが報告されてい

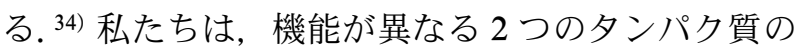
変異により同様の表現型を示すことから，「小胞体 上で ABCD4 が LMBD1 とアセンブルすることに よりリソソームへ局在化し，ビタミン $\mathrm{B}_{12}$ 輸送に関 与する」(Fig. 10) のではないかと考えた.

最初に，ヒト肝がん由来 $\mathrm{HuH7}$ 細胞に, $\mathrm{COOH}$

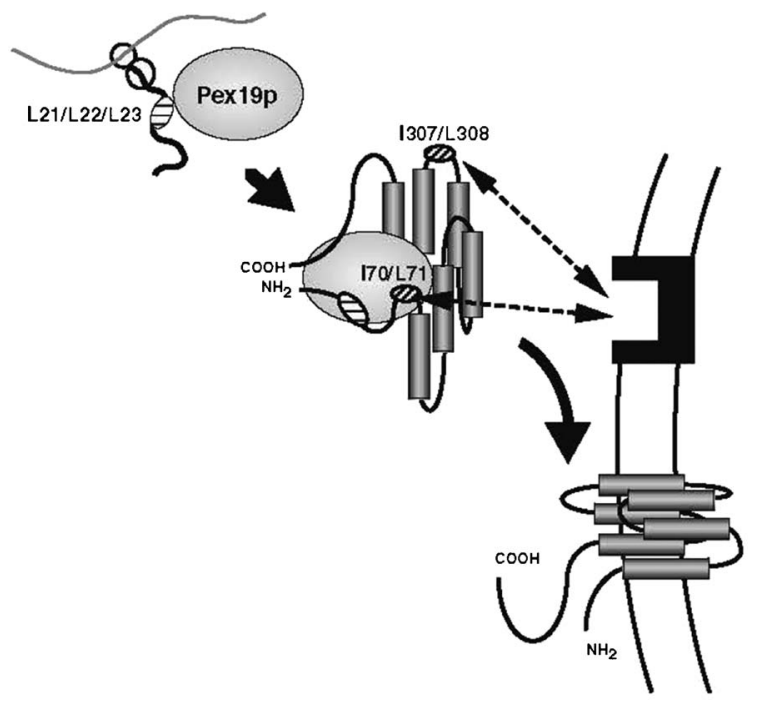

Peroxisomal membrane

Fig. 9. A Hypothetical Model for the Targeting of ABCD3 to Peroxisome

After being synthesized in the cytosol, $\mathrm{ABCD} 3$ is recognized by and bound to Pex19p at the $\mathrm{NH}_{2}$-terminal hydrophobic motif constituted by $\mathrm{Leu}^{21} \mathrm{Leu}^{22}-\mathrm{Leu}^{23}$ and the region of TMD5-TMD6. The ABCD3/PMP70Pex19p complex is transported to peroxisomes by the mPTSs located in the $\mathrm{NH}_{2}$-terminal 124-amino acid region and the region of ABCD3 (AA.263375) (the hydrophobicity of $\mathrm{Ile}^{70}-\mathrm{Leu}^{71}$ and $\mathrm{Il}^{307}-\mathrm{Leu}^{308}$ might be essential). Finally, $\mathrm{ABCD} 3$ is inserted into peroxisomal membranes through the unidentified proteinaceous components on the peroxisomal membranes. In this process, at least two TMDs are required for correct insertion.

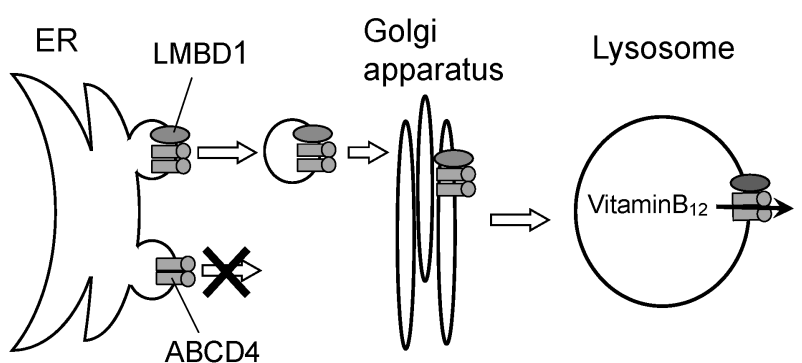

Fig. 10. ABCD4 Is Translocated from the ER to Lysosomes in Association with LMBD1

The newly synthesized ABCD4 is inserted into the ER membrane and assembles into a homodimer. ABCD4 then associates with the newly synthesized lysosomal membrane protein LMBD1 and the complex of ABCD4 with LMBD1 is transported to the lysosomes. ABCD4 stays on the ER membrane without LMBD1.

末端にHA タグを付加した融合タンパク質 ABCD4-HA を安定過剩発現させると小胞体に局在 したが，LMBD1-GFP を共発現させると，驚いた ことに ABCD4-HA の分布が細網状からドット状へ と劇的に変化し，その分布は LMBD1-GFP 及びリ ソソーム膜タンパク質 LAMP1 の分布と一致し た. 実際，ABCD4 のダイマーが LMBD1 と複合体 を形成していた。 また，LMBD1 のリソソーム移行 シグナルと予想される $\mathrm{Tyr}^{233}-\mathrm{Glu}^{234}-\mathrm{Arg}^{235}-\mathrm{Leu}^{236}$ を 
それぞれ Ala に置換すると LMBD1 は ABCD4 を 伴って細胞膜に移行した．さらに，CRISPR/Cas9 法で LMBD1 をコードする $L M B R D 1$ 遺伝子を破壊 した HEK293 細胞を作製した. ABCD4 の分布につ いてみると，野生型細胞では小胞体及びリソソーム と重なる 2 つピークが存在し， LMBRD1 破壊細 胞では, リソソームと重なるピークが野生型の $40 \%$ 以下にまで減少し，逆に小胞体と重なるピークが増 加していた。 すなわち，内在性の ABCD4 は小胞体 及びリソソームの両方に局在し，その小胞体からリ ソソームへの移行が，LMBD1 に制御されているこ とが明らかとなった。吕)これは，ABCトランス ポーターの細胞内局在が，アダプタータンパク質に よって決定されるという初めての報告である.

$\mathrm{ABCD}$ タンパク質のオルガネラ局在化をみると, $\mathrm{TMD} 1$ までの $\mathrm{NH}_{2}$ 末端のアミノ酸配列がタンパク 質の小胞体への局在化を抑制している。一方, $\mathrm{ABCD} 3$ の実験で, $\mathrm{NH}_{2}$ 末端のアミノ酸配列 （AA.1-80） は H0 モチーフを含むがミトコンドリ アに輸送され，TMD1 と TMD2 が加わるとペルオ キシソームへ移行する. ${ }^{36)} \mathrm{ABCD} 3$ は，まずは小胞 体への移行をミトコンドリアへの移行に必要な HSP70 などとの結合で回避し，その後 TMD1 と TMD2 とで Pex19p との強い結合にシフトし, ペル オキシソームへ移行しているのではないだろうか. オルガネラの表面積を比較すると, 小胞体が最も広 く，ミトコンドリアと比べてもペルオキシソームは 非常に狭い。よって，生体はペルオキシソームに膜 タンパク質を効率よく局在化させるために小胞体と ミトコンドリアへの局在化を防ぐ手段を獲得したと 思われる。

\section{4. ペルオキシソームの機能}

4-1. ペルオキシソーム機能の概要 ヒトペル オキシソームには 50 種類以上の酵素が局在し, ペ ルオキシソーム特有の代謝に係わっている. ${ }^{7)}$ 私た ちは，ラット肝臟ペルオキシソームのプロテオーム 解析により，ペルオキシソームタンパク質の品質管

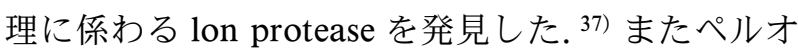
キシソームには PTS1 を持つ insulin degrading enzyme が局在し，インスリンの分解ではなく酸化夕 ンパク質の分解に係わることを報告した. ${ }^{38)}$ また酵 母 Saccharomyces cerevisiae において，ペルオキシ ソームへの ATP 輸送に係わる ATP/AMP 交換輸
送体を発見した. ${ }^{39)}$

脂肪酸の $\beta$ 酸化はペルオキシソームにおける重 要な代謝経路である。ペルオキシソームでは，極長 鎖脂肪酸，分枝脂肪酸，胆汁酸生合成中間体ジヒド ロキシコレスタン酸やトリヒドロキシコレスタン 酸，長鎖ジカルボン酸， 2 ヒドロキシ脂肪酸，プロ スタノイドなどが $\beta$ 酸化される。 また，エーテル 型リン脂質の生合成，フィタン酸の $\alpha$ 酸化が行わ れている。脂質代謝以外では，プリン，ポリアミ ン，グリオキシル酸，アミノ酸の代謝にも係わって いる. 最近, ペルオキシソームの新たな機能が報告 された。ペルオキシソームはミトコンドリアととも に自然免疫反応におけるシグナル伝達のプラット ホームとして働いている. ${ }^{40)}$ また，ペルオキシソー ムはコレステロールのリソソームから小胞体への輸 送において，リソソームとの接触が必要らしい. ${ }^{41)}$ ペルオキシソームはミトコンドリア，リソソーム， 小胞体などとも相互作用し，多様な生命現象に係 わっている。

4-2. ABCD タンパク質の機能 ペルオキシ ソームへの物質の取り込みと代謝産物の排出にはト ランスポーターを必要とする。関与するトランス ポーターのうち，1つが $\mathrm{ABC}$ タンパク質である. 脂肪酸は主として CoA 体として細胞質に存在して いるので，各種の acyl-CoA はペルオキシソームで 酸化される前に $\mathrm{ABC}$ タンパク質によってペルオキ シソーム内に輸送される。一方， $\beta$ 酸化され鎖長が 短くなった acyl-CoA は carnitine, taurine/glycine 誘導体に変換されて cation/ carnitine transporter （OCNT3）などを介してペルオキシソームから排出 される. ${ }^{42)}$

ヒト ABC タンパク質に関しては，NBD を欠く $\mathrm{ABCC} 13$ を含めると 49 種が同定され，A-F のサブ ファミリーに分類されている. ${ }^{43)}$ サブファミリー D には，ABCD1-4の 4 種の ABCD タンパク質が存 在する.これらは主としてホモダイマーとして機能 している. 最近 ABCD1 と ABCD2 がへテロテトラ マーを形成しているとの報告もある. ${ }^{44)} \mathrm{ABCD} 1-3$ は Fig. 11 に示すように極長鎖脂肪酸 CoA，長鎖脂 肪酸 $\mathrm{CoA}$, 分枝脂肪酸 $\mathrm{CoA}$ や胆汁酸生合成中間体 の $\mathrm{CoA}$ を輸送している。 $\mathrm{ABCD} 1$ と $\mathrm{ABCD} 2$ では 極長鎖脂肪酸に対する基質特異性がオーバーラップ している. ${ }^{45-47)}$ 一方, ABCD4 はリソソームから細 


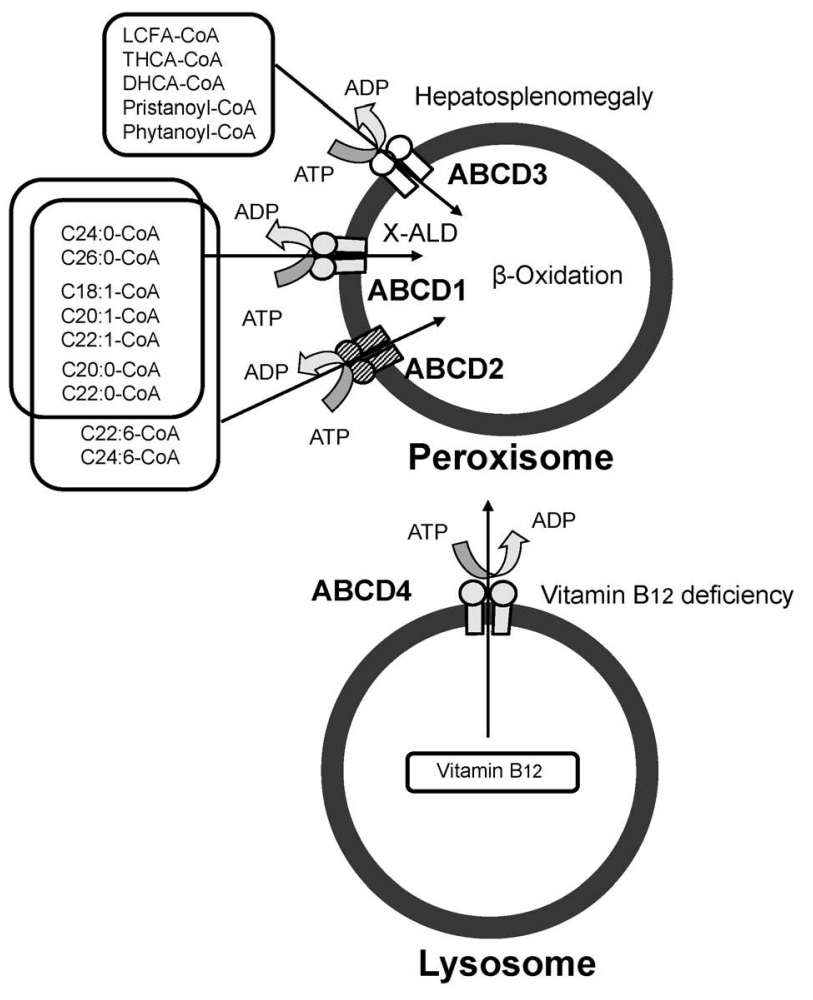

Fig. 11. Potential Substrates of ABCD Transporters $\mathrm{ABCD} 1-3$ predominately exist as a homodimer. $\mathrm{ABCD} 1$ and $\mathrm{ABCD} 2$ have overlapping substrate specificities toward saturated and monounsaturated VLCFA-CoAs. However, ABCD1 has a higher specificity to C24:0$\mathrm{CoA}$ and $\mathrm{C} 26: 0-\mathrm{CoA}$ than $\mathrm{ABCD} 2$. In contrast, $\mathrm{ABCD} 2$ has higher specificity for $\mathrm{C} 22: 6-\mathrm{CoA}$ and $\mathrm{C} 24: 6-\mathrm{CoA}$. ABCD3 is thought to be involved in the transport of LCFA-CoA, branched chain acyl-CoA, and bile acid intermediates, THCA-CoA and DHCA-CoA. ABCD4 is deduced to be involved in the transport of vitamin $\mathrm{B}_{12}$ from lysosome to cytosol.

胞質へのビタミン $\mathrm{B}_{12}$ の輸送に関与していることが 示唆される. ${ }^{33)} \mathrm{ABCD} 1-4$ はいずれも膜上で NBD を細胞質に向けたトポロジーをとることから,

ABCD1-3 とABCD4 とでは基質輸送が逆方向にな ることは興味深い.ABCD4 は哺乳動物で初めて同 定された importer となる. Importer とは，基質を 細胞外から細胞内へ輸送するトランスポーターであ り, リソソームや小胞体などのオルガネラ内部は細 胞外に相当する.

$\mathrm{ABC}$ タンパク質は NBD での ATP の結合・加水 分解のサイクルにより構造変化を介して物質を輸送 している。私たちは ATP 結合・加水分解に伴う ラット肝臓ペルオキシソーム $\mathrm{ABCD} 3$ の構造変化を トリプシン感受性の違いを利用して解析を行い,

NBD の helical domain が ATP の結合・加水分解に

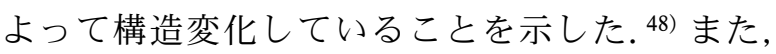

$\mathrm{ABCD} 1$ については基質結合により $\mathrm{NH}_{2}$ 末端側の $44 \mathrm{kDa}$ フラグメントの Factor Xa に対する感受性
が変化することが報告されている. ${ }^{49)}$ よって, $\mathrm{NH}_{2}$ 末端側の TMD が基質の認識に関与し， $\mathrm{COOH}$ 末 端側の NBD にATP が結合し構造変化することを 示唆している。最近，私は ABCD1-4 をメタノール 資化性酵母 Pichia pastoris に大量発現させることに 成功し, 精製後プロテオリポソームに組み込み, ABCD1-4 が ATPase 活性を持つことを示した. ${ }^{50)}$

4-2-1. ABCD1 ABCD1 の欠損は，組織にお ける極長鎖脂肪酸の蓄積を特徵とする副腎白質ジス トロフィー ( X-linked adrenoleukodystrophy; X-ALD）の原因となる.よって, ABCD1 はペルオ キシソームでの $\beta$ 酸化のために極長鎖脂肪酸をぺ ルオキシソームへ輸送するトランスポーターと考え られた。実際，X-ALD 患者線維芽細胞に $A B C D 1$ 遺伝子を導入すると, 極長鎖脂肪酸の $\beta$ 酸化が正 常化し，細胞内の極長鎖脂肪量が健常者の細胞と同 じレベルに低下する，ヒト ABCD タンパク質ホモ ログであるPxa1/Pxa2 を欠損させた S. cerevisiae に, ヒト ABCD1 を発現させて解析した結果から, ABCD1 が C18:0-, C22:0-, C24:0-, C26:0-, C18:1-, C24:6-CoA のような飽和，モノ不飽和，多価不飽 和脂肪酸-CoA の輸送に係わる可能性が示唆され た. ${ }^{45)}$

しかしながら， ABCD1 の極長鎖脂肪酸 $\mathrm{CoA} の$ 輸送機構はよくわかっていない。最近，シロイヌナ ズナにおけるヒト ABCD1 ホモログ COMATOSE （CTS）が acyl-CoA thioesterase 活性を有すること より，極長鎖脂肪酸 $\mathrm{CoA}$ は一旦 $\operatorname{CoA}$ が外れ，極 長鎖脂肪酸として輸送され，acyl-CoA synthetase によって再 CoA 化されるというモデルが提示され た. ${ }^{51)}$ また，ペルオキシソームの $\beta$ 酸化系酵素であ る thiolase を欠損させ, carnitine palmitoyltransferase 2-SKL をぺルオキシソームに発現させた $S$. cerevisiae を作製し, $\left[{ }^{18} \mathrm{O}\right] \mathrm{H}_{2} \mathrm{O}$ を含む培養液中でオ レイン酸の $\beta$ 酸化が解析された。その結果, $\left[{ }^{18} \mathrm{O}\right]$ で標識された $\beta$ 酸化中間体 3-OH-C18:1-carnitine を定量することにより, acyl-CoA は一旦 CoA が外 れ再 CoA 化を受けた後に代謝されることが示唆さ れた. ${ }^{52)}$ 一方，ヒ卜線維芽細胞から分離したペルオ キシソームで極長鎖脂肪酸 $\mathrm{CoA}$ の $\beta$ 酸化活性が $\mathrm{CoA}$ 添加で増加しないことより，極長鎖脂肪酸 CoA はそのまま輸送される可能性を示す報告もあ る. ${ }^{53)}$ 
最近，私はヒト ABCD1 をP. pastoris に発現さ せ，ABCD1 が acyl-CoA thioesterase 活性を持つこ とを示した. ${ }^{50)}$ 今後, acyl-CoA 輸送に ABCD1の ATPase 活性と acyl-CoA thioesterase 活性がぞのよ うな役割を果たしているかなど輸送メカニズムの解 明が望まれる。また， ABCD1 を欠損するとリソ ソームからのコレステロールの排出が低下すること が報告された. ${ }^{41)}$ そのメカニズムは不明であるが, ペルオキシソームとリソソームのクロストークがど のようにコレステロール代謝に影響するかも興味深 い.

4-2-2. ABCD2 ABCD2 は ABCD1 と機能的 なオーバーラップがある。実際，X-ALD の患者線 維芽細胞に $\mathrm{ABCD} 2 \mathrm{cDNA}$ を導入すると，極長鎖 脂肪酸の $\beta$ 酸化を正常化する。一方, $\mathrm{ABCD} 2$ と $\mathrm{ABCD} 1$ のノックアウトマウスでは, 脂肪酸蓄積異 常のパターンが異なる. ABCD1ノックアウトマウ スでは $\mathrm{C} 24: 0$ や $\mathrm{C} 26: 0$ の顕著な蓄積増加がみられ るが，ABCD2 ノックアウトマウスでは 1 価並びに 多価不飽和極長鎖脂肪酸が蓄積する. ${ }^{54)}$ また，ヒト $\mathrm{ABCD} 1$ 並びに $\mathrm{ABCD} 2$ を $\mathrm{Pxa} 1 / \mathrm{Pxa} 2$ 欠損 $S$. cerevisiae に発現させた解析からも, $\mathrm{ABCD} 2$ が C22:6-CoA や C24:6-CoA の輸送に特異性が高いこ とが窥える. ${ }^{45)}$ また, ABCD1 と ABCD2 の発現 は，組織や細胞によって異なっている。どちらを発 現するかで組織によって利点があるのかもしれない.

$\mathrm{ABCD} 2$ の発現は, PPAR $\alpha, \mathrm{RXR}, \mathrm{TR} \beta, \mathrm{SREBP}$ などで制御されている. ${ }^{43)} \mathrm{ABCD} 2$ の発現はヒトで は低く, $A B C D 2$ 遺伝子の変異による疾患はまだ知 られていない.

4-2-3. ABCD3 ABCD3 は肝臓や腎臓におい てペルオキシソーム膜の主要タンパク質の 1 つであ る。私たちは, $\mathrm{ABCD} 3$ を $\mathrm{CHO}$ 細胞に安定過剩発 現させるとパルミチン酸の $\beta$ 酸化活性が充進する が, リグノセリン酸の $\beta$ 酸化活性は阻害されるこ とより, $\mathrm{ABCD} 3$ は長鎖脂肪酸の輸送に係わってい る可能性を示した. ${ }^{55)} \mathrm{ABCD} 3$ を Pxa1/Pxa2 欠損 $S$. cerevisiaeに発現させた実験から，ABCD3 は飽 和，不飽和長鎖脂肪酸，分岐長鎖脂肪酸，長鎖ジ力 ルボン酸，などの少し水溶性の高い脂肪酸の輸送に 係わつていると予想される（Fig. 11）. ${ }^{46)}$ 実際, $\mathrm{ABCD} 3$ ノックアウトマウスでは, 胆汁酸代謝の異 常がみられ，肝臓，胆汁や小腸でのタウリンやグリ
シン抱合したケノデオキシコール酸やコール酸の量 が低下し, 胆汁酸前駆体のトリヒドロキシコレスタ ン酸とジヒドロキシコレスタン酸が顕著に増加す る。食餌中に含まれるフィトール（葉緑素由来のジ テルペンアルコール）は腸内細菌によりフィタン酸 やプリスタン酸に変換され，ペルオキシソームで分 解される. よって, フィトール食を $\mathrm{ABCD} 3$ ノック アウトマウスに摂取させると, フィタン酸やプリス タン酸の代謝異常で, これら分枝脂肪酸の血中量が 増加する. 最近, $A B C D 3$ 遺伝子に変異を持つ患者 が発見され，ノックアウトマウス同様の代謝異常を 示し, 肝臓・膵臓脾腫と重篤な肝障害を示すことが 報告されている. ${ }^{47)}$

4-2-4. ABCD4 ABCD4 の遺伝子異常でリソ ソームにビタミン $\mathrm{B}_{12}$ が蓄積するビタミン $\mathrm{B}_{12}$ 欠乏 症患者が発見されたことより，ABCD4 はビタミン $\mathrm{B}_{12}$ のリソソームから細胞質への輸送に係わってい ると思われる。ビタミン $\mathrm{B}_{12}$ は血中でトランスコバ ラミン（TC）と複合体を形成し，細胞表面にある 受容体と結合したのち，エンドサイトーシスにより リソソーム内へと取り込まれる。 その後, リソソー ム内から細胞質, さらに一部ミトコンドリア内へと 輸送され, methionine synthase や methylmalonylCoA mutase の補酵素として利用される.

哺乳動物細胞では, 細胞外へのビタミン $\mathrm{B}_{12}$ の排 出を細胞膜上の $\mathrm{ABC}$ タンパク質 $\mathrm{ABCC} 1$ が担うこ

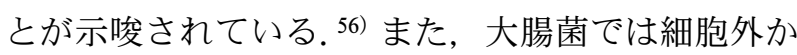
らのビタミン $\mathrm{B}_{12}$ の取り込みを細胞膜の $\mathrm{ABC}$ タン


ムにおいて，ビタミン $\mathrm{B}_{12}$ 輸送の本体は ABCD4 で あり LMBD1 は多種類のプロテアーゼを含む酸性 オルガネラであるリソソーム膜上で ABCD4 の安定 性に寄与しているかもしれない.

\section{5. ペルオキシソーム病}

ペルオキシソームの欠損では，極長鎖脂肪酸や フィタン酸などの物質が蓄積する。一方では, DHA，胆汁酸，プラズマローゲンなど生体に必須 の物質が減少する。ペルオキシソーム酵素やペルオ キシソームの形成に係わる遺伝子変異でいわゆるぺ ルオキシソーム病が起こる。ペルオキシソーム病 は，ペルオキシソーム形成に係わる疾患ペルオキシ ソーム形成異常症 (peroxisome biogenesis disease; PBD） と単一酵素異常症の 2 つに分類される. ${ }^{58)}$ 
5-1. ペルオキシソーム形成異常症ペルオキ シソームの形成は, ペルオキシソーム前駆体の小胞 体からの出芽, マトリックスタンパク質の輸送, 成 熟と分裂による増殖の過程から成り立っている。ペ ルオキシソーム形成異常症は, 常染色体の 2 つの対 立 $P E X$ 遺伝子の異常による劣性遺伝病である。こ れまでに 13 種類の $P E X$ 遺伝子の変異が報告され ていた．最近，ペルオキシソームの分裂に係わる遺 伝子 $D L P / D R P 1$ と $P E X 11 \beta$ の変異によるペルオキ シソーム形成異常症が報告された. ${ }^{59,60)}$

ペルオキシソーム形成異常症は, 臨床的には重篤 で致死的な疾患から比較的軽度で進行性の神経系疾 患まで幅広い。ペルオキシソーム形成異常症の共通 した病態は, 肝臓障害, 神経系の発達の遅れ, 網膜 症，聴覚障害などである。疾患の重篤度は，ペルオ キシソーム形成における peroxin の役割と変異 peroxin に残っている機能の程度に依存する，最も 重篤なケースは, Zellweger 病，新生児型副腎白質 ジストロフィー（X-ALD とは異なる疾患），乳児 型レフサム病である。これらの病名は原因遺伝子が 発見される以前につけられたので, 同じ遺伝子変異 でも重症度の程度と疾患の表現系の特徵により異な る病名がついている。 PEX1, PEX2, PEX3, PEX5, PEX6, PEX7, PEX10, PEX11, PEX12, PEX13, $P E X 14, P E X 16, T E X 19, P E X 26, D L P / D R P 1$ 遺伝 子の異常が報告されている.

$P E X 7$ 遺伝子の変異では PTS2 を持つペルオキシ ソームマトリックスタンパク質のペルオキシソーム への輸送が障害される致死性の骨系統疾患で点状石 灰化を伴う近位優位の四肢短縮症（rhizomelic chondrodyplasia punctate; RCDP) type 1 に分類さ れている。 Type 2, 3 及び 4 は単一酵素異常疾患 （後述）で, 最近 Pex5pL, DLP/DRP1, Pex11p $\beta$ の 遺伝子異常が Type 5 に分類されている.

\section{5-2. 単一酵素欠損症 単一酵素欠損症には,} ペルオキシソームマトリックス酵素と膜タンパク質 の欠損がある. 欠損症の病態は，それぞれのタンパ ク質のペルオキシソーム代謝における役割に依存す る. 単一酵素欠損症も生化学的異常を示し, 多くの 場合重篤である.脂肪酸 $\beta$ 酸化系酵素の欠損とし ては, acyl-CoA oxidase 欠損症, D-bifunctional protein (multifunctional protein 2; MFP2) 欠損症, 2-methylacyl-CoA racemase 欠損症, sterol carrier protein X (SCPx) 欠損症が知られている. $\alpha$ 酸化 酵素 phytanoyl-CoA hydroxylase の欠損はレフサム 病（乳児型レフサム病とは異なる）の原因となる. エーテル型リン脂質生合成に係わる acyl-CoA: dihydroxyacetonephosphate acyltransferase (DHAPTA), alkyl-DHAP synthase, fatty acyl-CoA reductase の欠 損は RCDP type 2，3，4 の原因となる. Alanine: glyoxylate amino transferase の欠損は原発性高シュ ウ酸尿症 type 1, catalase の欠損はアカタラセミア の原因となる。一方，トランスポーターである ABCD1 の欠損は X-ALD の原因となる。2016 年, 肝脾腫と重篤な肝臓障害を持つ $\mathrm{ABCD} 3$ 欠損症患者 が初めて見つかつた. ${ }^{47)}$

ペルオキシソーム病は重篤で稀な疾患であり, 治 療法の開発はこれからの課題である。一方，XALD については患者数も比較的多く, 病態解明や 治療法の開発が進められている.

\section{5-3. X-ALD}

5-3-1. X-ALD とは X-ALD は, ABCD1 夕 ンパクをコードする $A B C D 1$ 遺伝子の異常による X 連鎖性の遺伝性疾患である。中枢神経の進行性の脱 髄による神経変性と副腎不全を特徴とする（Fig. 12)。ペルオキシソーム病の中で患者数の最も多い 疾患で, 男児数万人に一人の割合で起こる。3-10 歳で発症して大脳半球に広範な進行性脱髄をきたす 小児大脳型のほかに，20 歳以降に痤性歩行で発症 する adrenomyeloneuropathy，成人で性格変化，知 能低下，精神症状で発症する成人大脳型，副腎不全 症状のみのアジソン型など，多彩な臨床型を有して いる.

X-ALD という疾患は, 1923 年に Siemerling と Creutzfeldt が副腎萎縮を伴う進行性脱髄疾患を報 告したことにはじまる。 ${ }^{61)} 1963$ 年，X-ALD は X 連 鎖劣性遺伝性の疾患であることが推測され, ${ }^{62} 1970$ 年にBlaw により中枢神経系と副腎皮質が障害され る先天代謝異常症として, “adrenoleukodystrophy” という名称が提唱された. ${ }^{63)}$ その後, 病変部に脂質 を蓄積した封入体（inclusion body）が発見され， 脂質代謝異常症であることが予想された。1976 年，五十嵐らにより患者の脳，副腎に極長鎖脂肪酸 が蓄積していることが示された. ${ }^{64)} 1993$ 年に Mosser らが，Xq28 上のポジショナルクローニングによ り, 本症の病因遺伝子として $A L D$ 遺伝子 (GenBank 



Fig. 12. MRI Images of a Boy with Cerebral X-ALD

Note the extensive white matter lesions involving the parieto-occipital white matter and splenium of the corpus callous. The left side is FLAIR image and the right side is $\mathrm{T} 1$-weighted image. The arrows show linear contrast enhancement.

NM_000033）を同定した。 ${ }^{65)} A L D$ は全長約 $21 \mathrm{~kb}$ で，10 個のエクソンを含み，745 アミノ酸からなる ペルオキシソーム膜 ABC タンパク質 (ALDP) を コードしていた。当初, 原因遺伝子は極長鎖脂肪酸 を活性型にする acyl-CoA synthase ではないかと推 定されていたので，ペルオキシソーム膜トランス ポーターが原因遺伝子であったことは驚きであった.

\section{5-3-2. 生化学的特徵と発症機構 中枢神経系} だけでなく，ほとんどの組織や血漿，赤血球膜，白 血球などにおいて極長鎖脂肪酸の増加が認められ る.これらの極長鎖脂肪酸はエステル体としてリン 脂質, ガングリオシド, コレテステロールエステル を構成している。一方, ドコサヘキサンエン酸 （DHA，C22:6）などの多価不飽和脂肪酸の含量は 増加していない. 血漿中の顕著な飽和極長鎖脂肪酸 (C26:0, C24:0) の増加は, X-ALD の最もよい診断 マーカーになっている. 最近, 1-ヘキサコサノイル2-リゾ-ホスファチジルコリン (C26:0-lyso-PC) の 血中での増加が, X-ALD やペルオキシソーム病の 有力な診断マーカーになることが指摘され，新生児 マススクリーニングへの応用も期待されている. ${ }^{66)}$

X-ALD では，脳グリア細胞や副腎皮質など $\mathrm{ABCD} 1$ が主として発現している細胞が障害のター ゲットになっている.X-ALDの発症機序の詳細は 不明であるが，まず，ABCD1 の機能不全により， 脳内グリア細胞であるアストロサイトやミクログリ アで極長鎖脂肪酸を含むリン脂質などが増加し，ミ トコンドリアの機能障害が起こる．引き続き，酸化 ストレスや自然免疫系の異常などを介してグリア細 胞から炎症性物質などが放出され，神経を取り囲ん でいるオリゴデンドロサイトの細胞の死により脱随

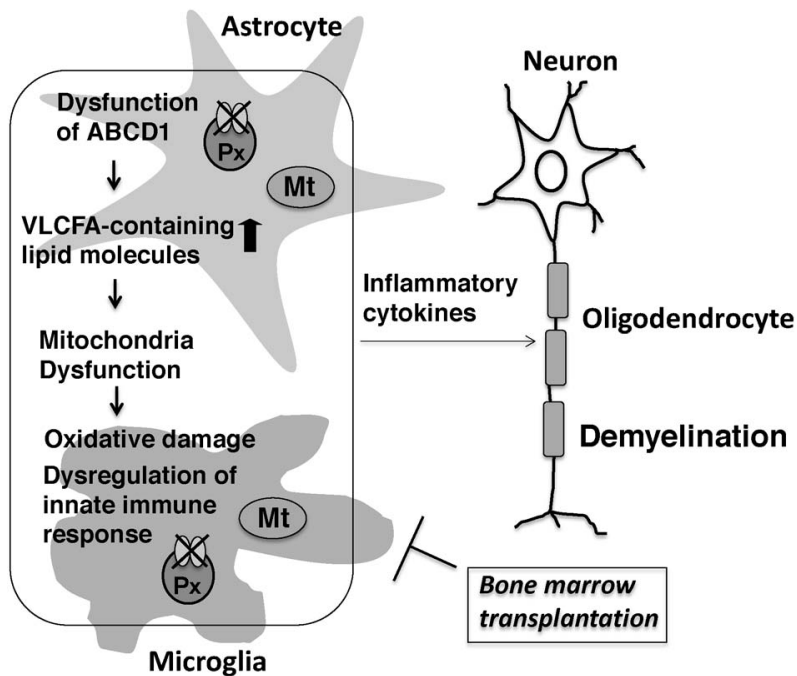

Fig. 13. A Putative Mechanism of Neurodegeneration in XALD

In the central nerve system, abnormal accumulation of very long chain fatty acids (VLCFAs), which is caused by the dysfunction of ABCD1 results in mitochondrial dysfunction. The dysfunction would exacerbate cell function through oxidative stress and might lead to dysregulation of innate immunity. The microglia secretes inflammatory cytokines. Proinflammatory cytokines are known to have negative affects on oligodendrocytes. Bone marrow transplantation may prevent progression of demyelination. Abbreviations: Px, peroxisome; Mt. mitochondrion.

が起こると考えられている (Fig. 13). ${ }^{43)}$

$\mathrm{X}-\mathrm{ALD}$ の特徵として, $A B C D 1$ 遺伝子に同じ変 異を持つ患者でも, 発症時期（病気の進行）に大き な違いがみられる。これは, $A B C D 1$ 遺伝子の変異 に加えて，他の遺伝子変異や環境などの修飾因子の 関与が重要であることを意味している. よって, 修 飾因子を同定し，その影響を改善することは病気の 進行を抑制するために重要である.

5-3-3. X-ALD の治療薬の開発 現在のとこ ろ, X-ALD の有効な治療法は確立されていない. 以前 X-ALD の治療に有効であると報告されたトリ オレインとトリエルシン（エルカ酸トリアシルグリ セロール）を 4:1 で配合したロレンツオオイル （Lorenzo’s oil）は，血中の極長鎖脂肪酸量を低下 させるが神経変性を抑制する効果はない。唯一, 発 病初期（発病前）における造血幹細胞移植が，病気 の進行を抑制できるが，拒絶反応などの移植のリス クも課題になっている.

治療薬開発に関しては, (1)変異型 ABCD1 の多く はペルオキシソームに輸送される前に分解されるの で, 変異型 $\mathrm{ABCD} 1$ タンパク質分解を抑制する化合 物の探索, (2)ABCD1 の機能を代行できる ABCD2 の発現誘導, (3)X-ALD 患者の細胞ではペルオキシ 




Fig. 14. Possible Targets for X-ALD Therapy

Mutation of ABCD1 leads to the dysfunction of $A B C D 1$, which results in a decrease in VLCFA $\beta$-oxidation. The decrease in VLCFA $\beta$-oxidation leads to an increase in the VLCFA-CoA level, which is the substrate for fatty acid elongation in the ER. As a result, the VLCFA level is increased and the subsequent abnormal accumulation of VLCFAs results in oxidative damage. 1. Stabilization and correct subcellular localization of missense mutants of ABCD1 with residual activity might be an effective way to recover the dysfunction of ABCD1. 2. Induction of ABCD2 expression. 3. Stimulation of peroxisomal fatty acid $\beta$-oxidation, 4. Inhibition of microsomal fatty acid elongation. 5. Attenuation of the dysregulated response to oxidative stress also has potential as an effective approach in X-ALD. Chemical compounds that can pass through blood-brain barrier and act on these targets would be promising drugs for X-ALD therapy since target cells in X-ALD are astrocytes and microglial cells in the central nervous system.

ソームでの極長鎖脂肪酸 $\beta$ 酸化活性が $30-40 \%$ 残つ ているので, ペルオキシソームの機能六進, (4)細胞 内での極長鎖脂肪酸合成に係わる酵素の阻害，(5) トコンドリアでの酸化ストレスを抑制する化合物の 探索などが課題となっている (Fig. 14). ${ }^{67)}$ 私たち はこの中で，(1)と(3)に関して新たな化合物のスク リーニング系を構築し, 有効化合物の探索を行って いる.

X-ALD 患者線維芽細胞において, ミスセンス変 異 ABCD1 のうち, 約 70\%の変異でタンパク質が 検出されないか若しくは減少している.この原因は, mRNA から翻訳された ABCD1 が正しく折り畳ま れず，プロテアソームで分解されてしまうためと考 えられている。，一方，変異 ABCD1 を持つ X-ALD 患者の線維芽細胞を, 体温 $\left(37^{\circ} \mathrm{C}\right)$ より低い温度 (26-30 $\left.{ }^{\circ} \mathrm{C}\right)$ で培養すると, 一部の変異型 $\mathrm{ABCD} 1$ は 分解が抑制され，ペルオキシソームに到達し，ペル オキシソームでの極長鎖脂肪酸の分解能をある程度 回復する.したがって，このようなミスセンス変異 を持つ変異 $\mathrm{ABCD} 1$ タンパク質を化合物で安定化し 機能を回復させることは，X-ALD に対する治療と して有効と考えられる.
私たちは，まず患者で見つかつているミスセンス 変異 $\mathrm{ABCD} 1$ タンパク質に GFPを融合した $\mathrm{ABCD} 1-\mathrm{GFP}$ を発現した $\mathrm{CHO}$ 細胞を作製した.こ の細胞でも変異型 $\mathrm{ABCD} 1-\mathrm{GFP}$ は， $37^{\circ} \mathrm{C}$ の培養条 件では分解されて GFP の蛍光は観察されないが, 低温培養やプロテアソーム阻害剂で分解を抑えると 蛍光が観察できる。このモデル細胞を 96 穴プレー 卜上で培養し, 変異型 ABCD1-GFP の蛍光の増加 を指標に，既存薬 1948 種についてスクリーニング を行った。その結果，多発性骨髄腫治療薬 bortezomib に変異型 ABCD1 を安定化する作用がみら れた。しかし， bortezomibには細胞障害もあり，

X-ALD 治療薬としての使用は難しいと思われるの で，新たな化合物の発見を目指している.

一方，X-ALD 患者線維芽細胞では極長鎖脂肪酸 $\beta$ 酸化活性が残っている. 最近, 遺伝子のエクソン 領域のみを濃縮して，DNA の塩基配列を解析する エクソーム解析により, 効率的にエクソン上の変異 を検出することが可能になった．X-ALD 患者の工 クソーム解析から，ペルオキシソームの機能が低く なる遺伝子変異を持っている患者ほど，重篤化する 可能性が示唆されている. よって, 極長鎖脂肪酸 $\beta$ 酸化活性の促進を含めてペルオキシソームの機能を 改善する化合物は治療薬の候補になると考えられ る. 私たちは, ヒト線維芽細胞にペルオキシソーム のみで $\beta$ 酸化されることを確認した蛍光化合物ピ レンで標識したパルミチン酸を添加し， $\beta$ 酸化され て炭素鎖の短くなつた脂肪酸を高速液体クロマトグ ラフィーで検出する方法を開発した. ${ }^{68)}$ 現在，96 穴 のプレートでX-ALD 患者の線維芽細胞を培養し, 脂肪酸 $\beta$ 酸化活性を促進させる化合物の検索を 行っている.

5-3-4. 新たな取り組み骨髄移植はX-ALD の唯一の治療法であるが, 移植による拒絶反応の問 題がある。 そこで, 最近では遺伝子治療が試みられ ている。 2009 年, フランスの Auborg らにより $A B C D I \mathrm{cDNA}$ を, lentivirus ベクターを用いて患者 造血幹細胞に導入し, 移植する遺伝子医療が行われ た. ${ }^{69)}$ MRI 検查によると, 移植 3 年を経過しても 脳での脱髄の進行が抑制されている.この結果を受 け，アメリカで 17 例の遺伝子治療が行われ 1 例を


功例は画期的である。しかし, 発症極初期若しくは 
未発症患者の遺伝子治療であり, 今後, どの程度の 病態の患者まで移植可能であるかとともに長期に渡 るフォローアップも必要である.

造血幹細胞移植は脱髄を抑制するが，その作用入 カニズムの詳細は不明である。私たちは，X-ALD モデルマウスを用いて，骨䯣移植の有効性を検討し ている，ちなみに，ドナー細胞は脳，春髄において ミクログリア様細胞に分化し，脳の広域に生着して いることが明らかになった．正常ミクログリアが分 泌するサイトカイン等の病態への影響などを解析す ることにより，新たな視点からの創薬が可能になる と思われる。

X-ALD では，発症時期と病態の進行・重症度は 患者毎に大きく異なっている，発症早期の骨䯣移植 が唯一の治療法であり，発症を予知できるバイオ マーカーの発見が求められている．X-ALD の診断 には，血漿・血清脂質加水分解後の脂肪酸組成分析 による C26:0/C22:0 值が用いられているが，病態 の程度を反映していない。発症や病態形成には多様 な極長鎖脂肪酸を含有した脂質分子種が関与する可 能性があるため, 発症機序の解明には本来の脂質分 子種を解析することが必要である。近年著しく発展 した LC/MS/MS を用いて網羅的に極長鎖脂肪酸含 有脂質を高感度に定量し構造決定することが可能に なった. ${ }^{71)}$ よって，特定の極長鎖脂肪酸含有脂質の 増加と病態の進行 ・重症度との相関性を解析するこ とで，病態の進展を予測できる新たなバイオマー カーが見つかることが期待される.

また X-ALD 患者線維芽細胞から iPS 細胞を作製 し，オリゴデンドロサイトに分化させることにより 病態を解析する試みが報告されている. ${ }^{72)}$ 遺伝子発 現解析による発病関連遺伝子の同定，分子病態解析 の進展が期待される.

X-ALD は， $A B C D 1$ 遺伝子の同一変異でも多様 な病態を示すことより，病気の進行に係わる $\mathrm{ABCD} 1$ 以外の遺伝子変異の存在が予測される. 多 数の X-ALD 患者の遺伝子のエクソーム解析を行い, X-ALD と関連した遺伝子異常が見い出されれば, 新たな視点からの創薬が可能になる。これらの取り 組みと治療薬開発があいまって，X-ALD の治療が 可能になると期待される.

6. おわりに

1985 年以降, 一貫して「ペルオキシソームの形
成機構と機能の解析並びに特定疾患であるX-ALD の病態解析と治療薬開発」に取り組んできた。これ までの研究を振り返り，私たちの研究を中心にぺル オキシソームの形成機構と機能並びにペルオキシ ソームに係わる疾患についてまとめた．科学技術の 進展とその応用により，ペルオキシソームがどのよ うに形成されるか，またどのような機能を担ってい るか，その理解は大いに深まった。一方，あること がわかると，「ではなぜそうなのだろうか」と新た な問いかけが出てくるのが科学である．新たにわ かつた知見をより深く検証し，ペルオキシソームの より深い理解が進むことが望まれる。またペルオキ シソームはミトコンドリア，小胞体などと代謝産物 の受け渡しを介して相互作用している。これらオル ガネラとのコミュニケーションと細胞機能制御の関 連性についての研究も重要である.

ペルオキシソーム病に関しては，原因遺伝子の特 定とともに病態の理解が進んできた．現在，治療法 の開発が進んでいるのはX-ALD のみであるが，近 い将来 X-ALD の有効な治療法が確立され，すべて のペルオキシソーム病の治療法開発のモデルとなる ことを期待される.

謝辞 ペルオキシオームに関する研究を進める にあたり，苦楽をともにした帝京大学薬学部病態生 化学研究室（故高野達哉教授）並びに富山大学大学 院医学薬学研究部細胞機能学研究室の先生方並びに 学生，共同研究を実施した多くの大学・企業の研究 者の皆様に感謝いたします。多くの方々とペルオキ シソームについての概念を共有できたことは大きな 喜びです.

利益相反＼cjkstart開示すべき利益相反はない.

\section{REFERENCES}

1) Rhodin J., Thesis, Karolinska Institutet, Aktiebolaget Godvil, Stockholm, 1954.

2) De Duve C., Baudhuin P., Physiol. Rev., 46, 323-357 (1966).

3) Lazarow P. B., De Duve C., Proc. Natl. Acad. Sci. USA, 73, 2043-2046 (1976).

4) Bowen P., Lee C. S., Zellweger H., Lindenberg R., Bull. Johns Hopkins Hosp., 114, 402-414 (1964). 
5) Goldfischer S., Moore C. L., Johnson A. B., Spiro A. J., Valsamis M. P., Wisniewski H. K., Ritch R. H., Norton W. T., Rapin I., Gartner L. M., Science, 182, 62-64 (1973).

6) Berger J., Dorninger F., Forss-Petter S., Kunze M., Biochim. Biophys. Acta, 1863, 934-955 (2016).

7) Waterham H. R., Ferdinandusse S., Wanders R. J., Biochim. Biophys. Acta, 1863, 922-933 (2016).

8) Vamecq J., Cherkaoui-Malki M., Andreoletti P., Latruffe N., Biochimie, 98, 4-15 (2014).

9) Haanstra J. R., González-Marcano E. B., Gualdrón-López M., Michels P. A., Biochim. Biophys. Acta, 1863, 1038-1048 (2016).

10) Steinberg G., Harmer N. J., Schuster M., Kilaru S., Fungal Genet. Biol., 109, 53-55 (2017).

11) Graham I. A., Annu. Rev. Plant Biol., 59, 115-142 (2008).

12) Novikoff P. M., Novikoff A. B., J. Cell Biol., 53, 532-560 (1972).

13) Lazarow P. B., Fujiki Y., Annu. Rev. Cell Biol., 1, 489-530 (1985).

14) Agrawal G., Subramani S., Biochim. Biophys. Acta, 1863, 892-901 (2016).

15) Imanaka T., Small G. M., Lazarow P. B., J. Cell Biol., 105, 2915-2922 (1987).

16) Gould S. G., Keller G. A., Subramani S., J. Cell Biol., 105, 2923-2931 (1987).

17) Gould S. J., Keller G. A., Subramani S., J. Cell Biol., 107, 897-905 (1988).

18) Rucktäschel R., Girzalsky W., Erdmann R., Biochim. Biophys. Acta, 1808, 892-900 (2011).

19) Hasan S., Platta H. W., Erdmann R., Front. Physiol., 4, 261 (2013).

20) Fujiki Y., Nashiro C., Miyata N., Tamura S., Okumoto K., Biochim. Biophys. Acta, 1823, 145-149 (2012).

21) Santos M. J., Imanaka T., Shio H., Lazarow P. B., J. Biol. Chem., 263, 10502-10509 (1988) .

22) Santos M. J., Imanaka T., Shio H., Small G. M., Lazarow P. B., Science, 239, 1536-1538 (1988).

23) Imanaka T., Shiina Y., Takano T., Hashimoto T., Osumi T., J. Biol. Chem., 271, 37063713 (1996).
24) Fang Y., Morrell J. C., Jones J. M., Gould S. J., J. Cell Biol., 164, 863-875 (2004).

25) Shibata H., Kashiwayama Y., Imanaka T., Kato H., J. Biol. Chem., 279, 38486-38494 (2004).

26) Sato Y., Shibata H., Nakatsu T., Nakano H., Kashiwayama Y., Imanaka T., Kato H., EMBO J., 29, 4083-4093 (2010).

27) Sato Y., Shibata H., Nakano H., Matsuzono Y., Kashiwayama Y., Kobayashi Y., Fujiki Y., Imanaka T., Kato H., J. Biol. Chem., 283, 6136-6144 (2008).

28) Kashiwayama Y., Seki M., Yasui A., Murasaki Y., Morita M., Yamashita Y., Sakaguchi M., Tanaka Y., Imanaka T., Exp. Cell Res., 315, 190-205 (2009).

29) Lee A., Asahina K., Okamoto T., Kawaguchi K., Kostsin D. G., Kashiwayama Y., Takanashi K., Yazaki K., Imanaka T., Morita M., Biochem. Biophys. Res. Commun., 453, 612-618 (2014).

30) Kashiwayama Y., Asahina K., Shibata H., Morita M., Muntau A. C., Roscher A. A., Wanders R. J., Shimozawa N., Sakaguchi M., Kato H., Imanaka T., Biochim. Biophys. Acta, 1746, 116-128 (2005).

31) Kashiwayama Y., Asahina K., Morita M., Imanaka T., J. Biol. Chem., 282, 33831-33844 (2007).

32) Halbach A., Lorenzen S., Landgraf C., Volkmer-Engert R., Erdmann R., Rottensteiner H., J. Biol. Chem., 280, 21176-21182 (2005).

33) Coelho D., Kim J. C., Miousse I. R., Fung S., du Moulin M., Buers I., Suormala T., Burda P., Frapolli M., Stucki M., Nürnberg P., Thiele H., Robenek H., Höhne W., Longo N., Pasquali M., Mengel E., Watkins D., Shoubridge E. A., Majewski J., Rosenblatt D. S., Fowler B., Rutsch F., Baumgartner M. R., Nat. Genet., 44, 1152-1155 (2012).

34) Rutsch F., Gailus S., Miousse I. R., Suormala T., Sagné C., Toliat M. R., Nürnberg G., Wittkampf T., Buers I., Sharifi A., Stucki M., Becker C., Baumgartner M., Robenek H., Marquardt T., Höhne W., Gasnier B., Rosenblatt D. S., Fowler B., Nürnberg P., Nat. Genet., 41, 234-239 (2009).

35) Kawaguchi K., Okamoto T., Morita M., Ima- 
naka T., Sci. Rep., 6, 30183 (2016).

36)

Iwashita S., Tsuchida M., Tsukuda M., Yamashita Y., Emi Y., Kida Y., Komori M., Kashiwayama Y., Imanaka T., Sakaguchi M., J. Biochem., 147, 581-590 (2010) .

37) Kikuchi M., Hatano N., Yokota S., Shimozawa N., Imanaka T., Taniguchi H., J. Biol. Chem., 279, 421-428 (2004).

38) Morita M., Kurochkin I. V., Motojima K., Goto S., Takano T., Okamura S., Sato R., Yokota S., Imanaka T., Cell Struct. Funct., 25, 309-315 (2000).

39) Nakagawa T., Imanaka T., Morita M., Ishiguro K., Yurimoto H., Yamashita A., Kato N., Sakai Y., J. Biol. Chem., 275, 34553461 (2000).

40) Dixit E., Boulant S., Zhang Y., Lee A. S., Odendall C., Shum B., Hacohen N., Chen Z. J., Whelan S. P., Fransen M., Nibert M. L., Superti-Furga G., Kagan J. C., Cell, 141, 668681 (2010).

41) Chu B. B., Liao Y. C., Qi W., Xie C., Du X., Wang J., Yang H., Miao H. H., Li B. L., Song B. L., Cell, 161, 291-306 (2015) .

42) Antonenkov V. D., Hiltunen J. K., Biochim. Biophys. Acta, 1822, 1374-1386 (2012).

43) Morita M., Imanaka T., Biochim. Biophys. Acta, 1822, 1387-1396 (2012) .

44) Geillon F., Gondcaille C., Raas Q., Dias A. M. M., Pecqueur D., Truntzer C., Lucchi G., Ducoroy P., Falson P., Savary S., Trompier D., J. Biol. Chem., 292, 6965-6977 (2017) .

45) van Roermund C. W., Visser W. F., Ijlst L., Waterham H. R., Wanders R. J., Biochim. Biophys. Acta, 1811, 148-152 (2011).

46) van Roermund C. W., Ijlst L., Wagemans T., Wanders R. J., Waterham H. R., Biochim. Biophys. Acta, 1841, 563-568 (2014).

47) Ferdinandusse S., Jimenez-Sanchez G., Koster J., Denis S., Van Roermund C. W., SilvaZolezzi I., Moser A. B., Visser W. F., Gulluoglu M., Durmaz O., Demirkol M., Waterham H. R., Gökcay G., Wanders R. J., Valle D., Hum. Mol. Genet., 24, 361-370 (2015).

48) Kashiwayama Y., Morita M., Kamijo K., Imanaka T., Biochem. Biophys. Res. Commun., 291, 1245-1251 (2002).

49) Guimarães C. P., Sá-Miranda C., Azevedo J.
E., J. Hum. Genet., 50, 99-105 (2005) .

50) Okamoto T., Kawaguchi K., Watanabe S., Agustina R., Ikejima T., Ikeda K., Nakano M., Morita M., Imanaka T., Biochem. Biophys. Res. Commun., 496, 1122-1127 (2018).

51) De Marcos Lousa C., van Roermund C. W., Postis V. L., Dietrich D., Kerr I. D., Wanders R. J., Baldwin S. A., Baker A., Theodoulou F. L., Proc. Natl. Acad. Sci. USA, 110, 12791284 (2013).

52) van Roermund C. W., Ijlst L., Majczak W., Waterham H. R., Folkerts H., Wanders R. J., Hellingwerf K. J., J. Biol. Chem., 287, 2014420153 (2012).

53) Wiesinger C., Kunze M., Regelsberger G., Forss-Petter S., Berger J., J. Biol. Chem., 288, 19269-19279 (2013).

54) Fourcade S., Ruiz M., Camps C., Schlüter A., Houten S. M., Mooyer P. A., Pàmpols T., Dacremont G., Wanders R. J., Giròs M., Pujol A., Am. J. Physiol. Endocrinol. Metab., 296, E211-E221 (2009).

55) Imanaka T., Aihara K., Takano T., Yamashita A., Sato R., Suzuki Y., Yokota S., Osumi T., J. Biol. Chem., 274, 11968-11976 (1999) .

56) Beedholm-Ebsen R., van de Wetering K., Hardlei T., Nexø E., Borst P., Moestrup S. K., Blood, 115, 1632-1639 (2010).

57) Borths E. L., Poolman B., Hvorup R. N., Locher K. P., Rees D. C., Biochemistry, 44, 16301-16309 (2005).

58) Wanders R. J., Klouwer F. C., Ferdinandusse S., Waterham H. R., Poll-Thé B. T., Methods Mol. Biol., 1595, 329-342 (2017).

59) Waterham H. R., Koster J., van Roermund C. W., Mooyer P. A., Wanders R. J., Leonard J. V., N. Engl. J. Med., 356, 1736-1741 (2007).

60) Ebberink M. S., Koster J., Visser G., Spronsen F., Stolte-Dijkstra I., Smit G. P., Fock J. M., Kemp S., Wanders R. J., Waterham H. R., J. Med. Genet., 49, 307-313 (2012).

61) Siemerling E., Creutzfeldt H. G., Eur. Arch. Psych. Clin. Neurosci., 68, 217-244 (1923).

62) Fanconi A., Prader A., Isler W., Luethy F., Siebenmann R., Helv. Paediatr. Acta, 18, 480-501 (1963).

63) Blaw M., "Neurodystrophies and Neurolipidoses, Melanodermic type leukodystrophy 
(adrenoleukodystrophy)," ed by Vinken P. J., Bruyn G. W., North Holland Publishing Co., Amsterdam, 1970, pp. 128-133.

64) Igarashi M., Schaumburg H. H., Powers J., Kishmoto Y., Kolodny E., Suzuki K., J. Neurochem., 26, 851-860 (1976).

65) Mosser J., Douar A. M., Sarde C. O., Kioschis P., Feil R., Moser H., Poustka A. M., Mandel J. L., Aubourg P., Nature, 361, 726-730 (1993).

66) Hubbard W. C., Moser A. B., Tortorelli S., Liu A., Jones D., Moser H., Mol. Genet. Metab., 89, 185-187 (2006).

67) Morita M., Shimozawa N., Kashiwayama Y., Suzuki Y., Imanaka T., Curr. Drug Targets, 12, 694-706 (2011).

68) Morita M., Matsumoto S., Okazaki A., Tomita K., Watanabe S., Kawaguchi K., Minato D., Matsuya Y., Shimozawa N., Imanaka T., J. Inherit. Metab. Dis., 39, 725-731 (2016) .

69) Cartier N., Hacein-Bey-Abina S., Bartholomae C. C., Veres G., Schmidt M., Kutschera I., Vidaud M., Abel U., Dal-Cortivo L., Caccavelli L., Mahlaoui N., Kiermer V., Mittel- staedt D., Bellesme C., Lahlou N., Lefrère F., Blanche S., Audit M., Payen E., Leboulch P., l'Homme B., Bougnères P., Von Kalle C., Fischer A., Cavazzana-Calvo M., Aubourg P., Science, 326, 818-823 (2009).

70) Eichler F., Duncan C., Musolino P. L., Orchard P. J., De Oliveira S., Thrasher A. J., Armant M., Dansereau C., Lund T. C., Miller W. P., Raymond G. V., Sankar R., Shah A. J., Sevin C., Gaspar H. B., Gissen P., Amartino H., Bratkovic D., Smith N. J. C., Paker A. M., Shamir E., O’Meara T., Davidson D., Aubourg P., Williams D. A., N. Engl. J. Med., 377, 1630-1638 (2017).

71) Hama K., Nagai T., Nishizawa C., Ikeda K., Morita M., Satoh N., Nakanishi H., Imanaka T., Shimozawa N., Taguchi R., Inoue K., Yokoyama K., Lipids, 48, 1253-1267 (2013).

72) Jang J., Kang H. C., Kim H. S., Kim J. Y., Huh Y. J., Kim D. S., Yoo J. E., Lee J. A., Lim B., Lee J., Yoon T. M., Park I. H., Hwang D. Y., Daley G. Q., Kim D. W., Ann. Neurol., 70, 402-409 (2011). 